\title{
COMPARATIVE ANALYSIS OF GENES RELATED TO QUALITY OF OOCYTE IN BUFFALOES (Bubalus bubalis) AND CAMELS (Camelus dromedarius) UNDER IN VITRO CONDITIONS
}

\author{
A. El-Sayed ${ }^{1,2}$ \\ ${ }^{1}$ Department of Animal Production, Faculty of Agriculture, Cairo University, 12613 Giza, Egypt, ${ }^{2}$ Cairo \\ University Research Park at Faculty of Agriculture, 12613 Giza, Egypt \\ Email: (ashrafah99@yahoo.com)
}

\section{SUMMARY}

The quality of oocyte is one of the main determinants of in vitro embryo production success. Different approaches have been applied for analyzing oocyte qualities particularly gene expression analysis, which represents a new tool for selecting competent ones. Thus, the present study aimed at studying gene expression of morphologically good and poor immature oocytes of buffaloes and camels. A total of 360 COCs of buffaloes and camels $(n=180$ each) were selected to run this study. Out of which 90 were pooled in three replicates with 30 oocytes in each of the two groups (immature good and poor grade oocytes) were used for gene expression analysis after cumulus cells denudation. Total RNA was isolated from all samples using PicoPureTM RNA isolation kit, and then converted into cDNA via reverse transcription kit. Quantitative Real-Time PCR was performed using specific primers for a set of selected candidate genes regulating cell cycle (Cyclin B1 and PTTG1), transcription factor activity (OCT4), polyamine biosynthetic (ODC1), signal transduction and activation of transcription (STAT3) .

Quantitative real-time PCR results showed a higher expression of all the selected genes in good compared to poor grade oocytes except of STAT3 which showed a similar expression in camels' oocytes.

Keywords: Buffalo, camel, oocyte quality, gene expression

\section{INTRODUCTION}

Early embryonic development is supported by maternal mRNAs as well as synthesized and stored proteins in the cytoplasm of oogenesis (Rodman and Bachvarova, 1976). Maternal factors are critical for the development post fertilization and the maternalembryonic transition, when transcription of the embryonic genome becomes fully activated. Recent studies have revealed that genes expressed in oocytes and early embryos are conserved among species, since numerous orthologs have been found in mice and humans by in silico analysis (Stanton and Green, $2001 \& 2002)$. However, oocyte transcriptome and identity of key oocyte-expressed genes are still not fully understood.

Characterization of gene expression in oocytes will provide additional insight into the regulation of oocyte maturation, fertilization, and pre-implantation development. Oocyte quality is one of the main determinants of in vitro embryo production success, while culture conditions during in vitro embryo production are the key factor determining oocyte development to the blastocyst (Lonergan et al., 2001 \& 2003).

Selection of the quality oocytes for in vitro fertilization is assumed to be based on quality markers extracted from morphological criteria and biochemical parameters. As far as no molecular biomarker for oocyte quality has been established, thus, understanding the molecular mechanisms in oocytes is quite important for both reproductive biology and regenerative medicine (Hamatani et al., 2008).

Different approaches have been applied for analyzing oocyte with different qualities based on gene expression analysis (Wang and Sun, 2007; Pandey et al., 2010 and Prasad et al., 2010) as more precise and objective tools. Up to our knowledge, the only work discussing this issue in buffalo was reported by Prasad et al. (2010) and only one report has discussed the expressed sequence tags for Camelus dromedarius in different adult tissues (AlSwailem et al., 2010). In addition the mRNA transcript abundance of oocytes or embryos in camel has not yet been analyzed.

The present study was aimed at identifying the differences in selected transcripts (Cyclin B1, OCT4, PTTG1, STAT3 and ODC1) abundance of genes related to oocyte quality of buffalo and camel oocytes, which could be associated with oocyte developmental potential.

\section{MATERIALS AND METHODS}

\section{Oocyte collection and evaluation in vitro}

Ovaries were collected from a local abattoir, transported to the laboratory within $1-2 \mathrm{~h}$ in physiological saline solution at $30-35^{\circ} \mathrm{C}$ and washed once in $70 \%$ ethanol and twice with warm $\left(37^{\circ} \mathrm{C}\right)$ phosphate buffer saline (PBS) contained $50 \mathrm{ug} / \mathrm{ml}$ gentamicin. Cumulus-oocyte complexes (COCs) 
were recovered by slicing ovaries (Hamano and Kuwayama, 1993). The COCs were evaluated based on their morphological features. Oocytes have 3-5 layers of cumulus cells and homogenous granular cytoplasm were considered as a good quality, while those with less than three layers or denuded were considered as poor ones (Gordon, 2003). A total of 360 COCs of buffalo and camel $(n=180$ each) were selected of which 90 were pooled in three replicates with 30 oocytes in each of the good and poor oocytes to be used for gene expression analysis.

\section{Cumulus cells separation}

The surrounding cumulus cells were separated from immature oocytes by gentle pipetting in washing medium supplemented with hyaluronidase $1 \mathrm{mg} / \mathrm{ml}$. Cumulus free oocytes were washed twice in PBS and snap frozen separately in cryo-tubes containing $20 \mu 1$ of Lysis buffer [0.8 \% IGEPAL, 40 U/ $\mu 1$ RNasin (Promega Madison WI, USA), $5 \mathrm{mM}$ dithiothreitol (DTT) (Promega Madison WI, USA)]. Finally, samples were stored at liquid nitrogen at $196^{\circ} \mathrm{C}$ until RNA isolation.

\section{RNA isolation}

Total RNA was isolated using PicoPure ${ }^{\mathrm{TM}}$ RNA isolation kit (MDS Analytical Technologies GmbH,
Ismaning, Germany) according to manufacturer's instructions. Oocytes in a Lysis buffer were mixed with $100 \mu \mathrm{l}$ extraction buffer and incubated at $42{ }^{\circ} \mathrm{C}$ for $30 \mathrm{~min}$ to obtain complete Lysis of the samples and to release RNA. The extract was loaded onto a pre-conditioned purification column and centrifuged to allow the RNA to bind to the spin column. DNA digestion in the column was carried out using RNasefree DNase (Qiagen GmbH, Hilden, Germany). The column was washed twice with washing buffer and finally eluted with $12 \mu \mathrm{l}$ RNase free water. For each sample, cDNA synthesis was performed using oligo (dT) 23 primer, random primer and superscript reverse transcriptase II (Invitrogen, Karlsruhe, Germany) in addition to one micro-litre of oligo (dT) 23 primer and one micro-litre random primer were added to $10 \mu \mathrm{l}$ mRA sample and the mixture was incubated for $3 \mathrm{~min}$ at $70^{\circ} \mathrm{C}$ and then immediately chilled on ice. Eight micro-litres of the master mix containing $4 \mu \mathrm{l}$ of $5 \mathrm{x}$ first strand buffer, $2 \mu \mathrm{l}$ of $0.1 \mathrm{M}$ DTT, $1 \mu \mathrm{l}$ of dNTP $(10 \mathrm{pmol} / \mu \mathrm{l})$ and $0.3 \mu \mathrm{l}$ of RNase inhibitor and $0.7 \mu \mathrm{l}$ of SuperScript IITM reverse transcriptase (200 unit/ $\mu \mathrm{l})$ were added to the mixture and incubated for $90 \mathrm{~min}$ at $42^{\circ} \mathrm{C}$ followed by heat inactivation for $15 \mathrm{~min}$ at $70^{\circ} \mathrm{C}$. The synthesized cDNA was stored at $-20^{\circ} \mathrm{C}$ for further use.

Table 1. Details of the primers used for quantitative real-time PCR.

\begin{tabular}{|c|c|c|c|c|}
\hline $\begin{array}{l}\text { Gene } \\
\text { sympol }\end{array}$ & $\begin{array}{l}\text { Gene bank } \\
\text { accession } \\
\text { number }\end{array}$ & Primer sequences & $\begin{array}{l}\text { Annealing } \\
\text { temperature } \\
\left({ }^{\circ} \mathrm{C}\right)\end{array}$ & $\begin{array}{l}\text { Product } \\
\text { size (bp) }\end{array}$ \\
\hline PTTG1 & NM_004219 & $\begin{array}{l}\text { F: 5'- GAAGAGCACCAGATTGCGC -3' } \\
\text { R: 5'- GTCACAGCAAACAGGTGGCA -3 }\end{array}$ & 55 & 204 \\
\hline OCT4 & NM_174580 & $\begin{array}{l}\text { F: 5'- GATATACCCAGGCCGATGTG-3' } \\
\text { R: 5'- CTCGGTTCTCGATACTCGTC-3 }\end{array}$ & 53 & 240 \\
\hline Cyclin B & L48205 & $\begin{array}{l}\text { F: 5' -GAGGGGATCCAAACCTTTGTAGTGA- } \\
\text { 3' } \\
\text { R: 5'-CAATTTCTGGAGGGTACATTTCTTC-3' }\end{array}$ & 55 & 318 \\
\hline ODC1 & NM_174130 & $\begin{array}{l}\text { F: 5'-CAAAGGCCAAGTTGGTTTTAC-3' } \\
\text { F: 5'-CAGAGATGGCCTGCACAAAG-3' }\end{array}$ & 55 & 201 \\
\hline STAT3 & XM_001494674 & $\begin{array}{l}\text { F: 5'-CTGTACAGTGACAGCTTCCC-3' } \\
\text { F: 5'-GCAATCTCCATTGGCTTCTC-3' }\end{array}$ & 52 & 245 \\
\hline GAPDH & NM_001034034 & $\begin{array}{l}\text { F: 5'-ACCCAGAAGACTGTGGATGG-3' } \\
\text { R: 5'-ACGCCTGCTTCACCACCTTC-3' }\end{array}$ & 55 & 247 \\
\hline
\end{tabular}

\section{Quantitative real-time PCR analysis}

Real-time PCR primers were designed based on the cDNA sequences of the five transcripts available in GenBank (Table 1) using Primer Express version 2.0 software (Applied Biosystems, Foster City, CA). Quantitative analyses of cDNA samples from independent oocytes were performed in comparison with the bovine GAPDH gene (endogenous control), and were run in separate wells using $\mathrm{Mx3000}$ instrument (Stratagene).
Independent qRT-PCR (3 replicates for each group for each genotype) was performed in a $20-\mu \mathrm{l}$

reaction volume containing iTaq SYBR Green Supermix with ROX (Bio-Rad Laboratories, Munich, Germany), the cDNA samples and the specific forward and reverse primer. The thermal cycling parameters were set at $95^{\circ} \mathrm{C}$ for $3 \mathrm{~min}, 40$ cycles of $95^{\circ} \mathrm{C}$ for $15 \mathrm{sec}$ and $60^{\circ} \mathrm{C}$ for $1 \mathrm{~min}$. After the end of the last cycle, a dissociation curve was generated by starting the fluorescence acquisition at $60^{\circ} \mathrm{C}$ and 
taking measurements every 7 -second interval until the temperature reached $95^{\circ} \mathrm{C}$. The comparative cycle threshold (CT) method was used to quantify the expression levels as previously described by Bermejo-Alvarez et al. (2010).

Expressions of five different transcripts (Cyclin B1, OCT4, PTTG1, STAT3 and ODC1) were analyzed using real-time PCR and fold changes were calculated using $\Delta \Delta \mathrm{Ct}$ method.

\section{RESULTS}

Gene expression profiling of immature oocytes with different grades

\section{Buffalo (Bubalus bubalis)}

Results of quantitative real-time PCR showed higher expression of all the selected genes $(n=5)$ in good compared to poor grade oocytes (Figure 1). The highest ratio of change was recorded in Cyclin B1 and OCT4, where they showed over-expression in good grade by (2.5 fold change) followed by STAT3 (2 folds) and PTTG1 (1.6 folds), while the lowest change rate was recorded for ODC1 (1.2 folds).

\section{Camel (Camelus dromedarius)}

Results showed higher expression of all the selected genes in good compared to denuded oocytes except STAT3, which showed a similar expression in both good and poor oocytes. The higher expression was observed in OTC4 (1:3.4 folds) followed by PTTG1 (1:2.9 folds) and Cyclin B1 (1:2.4 folds). The lower expression was recorded by ODC1 $(1: 1.9$ folds) (Figure 2).

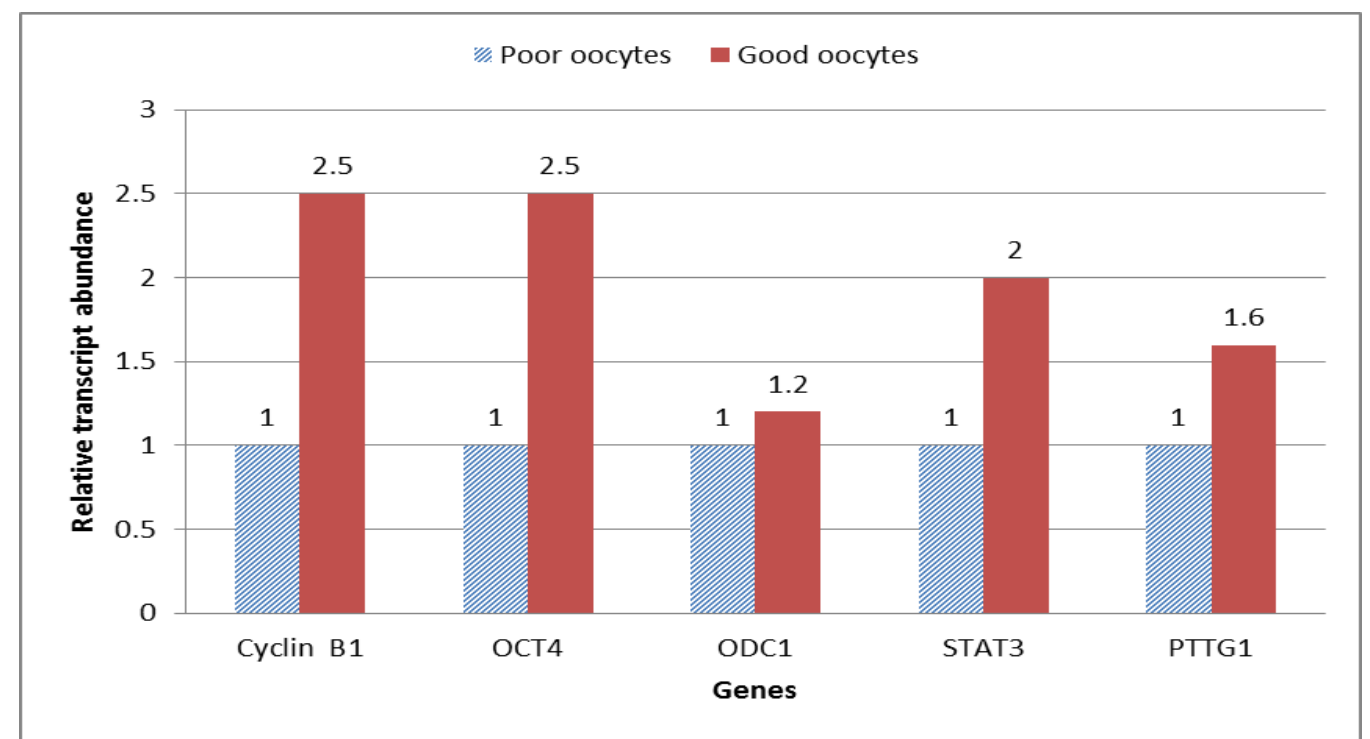

Figure 1. Differentially expressed transcript abundance of candidate genes for immature buffalo oocytes of good and poor quality

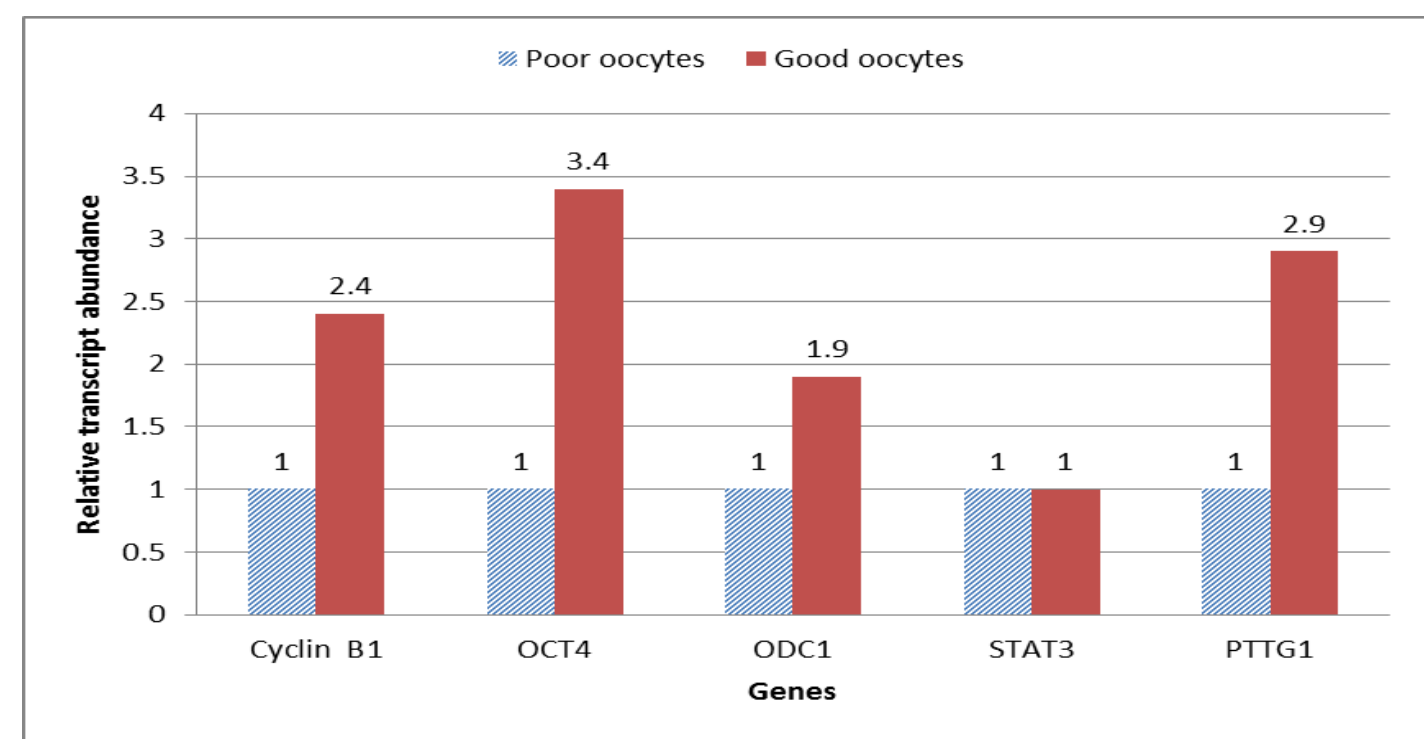

Figure 2. Differentially expressed transcript abundance of candidate genes for immature camel oocytes of good and poor quality 


\section{DISCUSSION}

Molecular characteristics of oocytes are important for the selection of oocytes of developmental capacity (Patel et al., 2007). Poor developmental capacity of bovine oocytes is assumed to be highly complicated and reliant on many small changes in the RNA levels of many genes (Donnison and Pfeffer, 2004).

The present results of Cyclin B1 in good and poor quality oocytes of buffaloes and camels are in agreement with the result of Hue et al. (1997) who reported that both Cyclin B1 mRNA and protein have been detected in meiotically competent and incompetent goat oocytes. The incompetent oocytes have a limited amount of Cyclin B1. Low expression of Cyclin B1 in poor quality oocytes reflects the importance of this gene for both quality and maturation of oocytes.

The obtained expression ratio of OCT-4 in good oocytes by more than 2 and 3 times compared to poor counterparts in both buffaloes and camels respectively is in agreement with the result obtained by Donnison and Pfeffer (2004). The authors reported 1.2 fold increase in OCT-4 transcript in oocytes derived from large follicles $(>5 \mathrm{~mm})$ relative to those derived from small ones $(<2 \mathrm{~mm})$. Moreover, Prasad et al. (2010) stated that, A and B grade oocytes showed strong OCT-4 expression. Naked oocytes showed faint or no detectable signal and as a result OCT-4 may be one of those specific genes whose expression is dependent on oocyte quality, suggesting that the lower developmental potential of naked oocytes might be due to the absence of OCT-4 transcripts.

ODC1 gene was up-regulated in good grade oocytes by 1.2 fold change compared to poor ones in buffaloes increased to 1.9 in camels' good grade oocytes. The present results reflect the importance of this transcript for the development and maturation. These results are confirmed by Paula-Lopes et al. (2007) and Torner et al. (2008). They reported an over-expression of this gene in competent bovine immature oocytes compared to incompetent counterparts. In addition, MohammadiSangcheshmeh et al. (2011) and Smits et al. (2011) found the same trend in equine oocytes.

STAT3 showed an increase in buffalo good grade oocytes by two times fold change compared to poor ones. This result is in agreement with the previous results on bovine obtained by Torner et al. (2008) and Mohammadi-Sangcheshmeh et al. (2011) who studied the expression level of this gene in equine oocytes. However, this gene showed similar expression in both good and poor grade camel oocytes. The opposite trend for this gene in camel compared to bovine and buffaloes need more studies at a large scale and using different models of oocyte selection. A lot of precautions should be paid when using different species as a model for camel in vitro embryo production application.
The relative abundance for PTTG1 was higher in good grade oocytes by 1.6 times in buffalo and 2.9 times in good grade compared to poor ones in camel oocytes. The present result is in contrary with the result obtained by Ghanem et al. (2007). In addition, PTTG1 gene was found to be up-regulated in embryo biopsies derived from blastocysts, which resulted in no pregnancy after transfer to recipients (El-Sayed et al., 2006). On the other side, this result supports the importance of this gene for further development as down-regulation of PTTG1 delays the resumption of meiosis and over-expression of PTTG1 permits the resumption of meiosis even in the presence of inhibitory concentrations of cAMP (Marangos and Carroll, 2008). Expression level for both cyclin B1 and PTTG1, in the present study, it could be speculated a relation between these two genes which is proofed by Marangos and Carroll (2008) who found that the depletion of PTTG1 increased CyclinB1 degradation, resulting in delayed progression into M-Phase of cell cycle during mouse oocyte maturation (Marangos and Carroll, 2008).

Collectively from the expression patterns of the selected genes for this study, it could be concluded that, the reported differences in developmental competence of buffalo and camel oocytes derived from different quality are also accompanied by differences in the relative abundance of transcripts related to the various molecular events and processes regulating oocyte competence. Our validation with an independent model for the relative abundance of some selected transcripts, supports the notion that many of the transcripts identified as differentially regulated and described here may represent marker candidate genes for oocyte developmental competence. However, the exact role of these transcripts in controlling oocyte developmental potential needs further investigation. To our knowledge, only one report has discussed one gene related to oocyte quality in buffalo (Prasad et al., 2010) and one report studied the expressed sequence tags for Camelus dromedarius in different adult tissues (Al-Swailem et al., 2010). The mRNA transcript abundance of oocytes in camel has not yet been analyzed. The present results have added new insights into IVF in camels at the molecular level. Many more studies are needed to explore the difference between this species and other species like bovine as it's the golden standard for farm animals at this level of research.

\section{ACKNOWLEDGEMENT}

The author would like to express his sincere appreciation to Prof. Ashraf Barkawi, Professor of Reproductive Physiology, Department of Animal Production, Faculty of Agriculture, Cairo University, for his very helpful comments, and corrections of the manuscript. 


\section{REFERENCES}

Al-Swailem, A. M., M. M. Shehata, F. M. AbuDuhier, E. J. Al-Yamani, and K. A. Al-Busadah, 2010. Sequencing, Analysis, and Annotation of Expressed Sequence Tags for Camelus dromedarius. PLoS ONE, 5(5): e10720

Bachvarova, R., 1985. Gene expression during oogenesis and oocyte development in mammals. In: BrowderL.W. (Ed.), Developmental Biology: A Comprehensive Synthesis, Vol. I: Oogenesis. Plenum Press, New York,pp. 453-524.

Bermejo-Alvarez, P., D. Rizos, D. Rath, P. Lonergan and A. Gutierrez-Adan, 2010. Sex determines the expression level of one third of the actively expressed genes in bovine blastocysts. Proc. Natl. Acad. Sci. USA, 107: 3394-3399

Donnison M. and P. L., Pfeffer, 2004. Isolation of genes associated with developmentally competent bovine oocytes and quantification of their levels during development. Biol. Reprod., 71: 18131821.

El-Sayed, A., M. Hoelker, F. Rings, D. Salilew, D. Jennen, E. Tholen, M-A. Sirard, K. Schellander and D. Tesfaye, 2006. Large-scale transcriptional analysis of bovine embryo biopsies in relation to pregnancy success after transfer to recipients. Physiol. Genomics, 28: 84-96.

Ghanem, N., M. Hölker, F. Rings, D. Jennen, E. Tholen, M-A. Sirard, H. Torner, W. Kanitz, K. Schellander, and D. Tesfaye, 2007. Alterations in transcript abundance of bovine oocytes recovered at growth and dominance phases of the first follicular wave. BMC. Dev. Biol., 7: 90.

Gordon, I., 2003. Recovering the bovine oocyte. In Laboratory production of cattle embryos, second edition, Gordon I. (Editor) Cambridge: CAB International/Cambridge University Press, pp. 79111.

Hamano, S., and M. Kuwayama, 1993. In vitro fertilization and development of bovine oocytes recovered from the ovaries of individual donors: A comparison between the cutting and aspiration method. Theriogenology 39(3): 703-712.

Hamatani, T., M. Yamada, H. Akutsu, N. Kuji, Y. Mochimaru, M. Takano, M. Toyoda, K. Miyado, A. Umezawa, and Y. Yoshimura, 2008. What can we learn from gene expression profiling of mouse oocytes. Reproduction, 135(5):581-592.

Hue, I., T. Dedieu, D. Huneau, S. Ruffini, L. Gall, and N. Crozet, 1997. Cyclin B1 expression in meiotically competent and incompetent goat oocytes. Mol. Reprod. Dev., 47:222-228.

Lonergan, P., D. Rizos, A. Gutierrez-Adan, T. Fair, and M. P. Boland, 2003. Oocyte and embryo quality: effect of origin, culture conditions and gene expression patterns. Reprod. Domest. Anim., 38(4):259-67
Lonergan, P., D. Rizos, F. Ward, and M. P. Boland, 2001. Factors influencing oocyte and embryo quality in cattle. Reprod. Nutr. Dev., 41: 427-437

Marangos, P., and J. Carrol, 2008. Securin regulates entry into M-phase by modulating the stability of cyclin B. Nat. Cell. Biol., 10: 445-451.

Mohammadi-Sangcheshmeh,A., E. Held, N. Ghanem, F. Rings, D. Salilew-Wondim ,D. Tesfaye, H. Sieme, K. Schellander, and M. Hoelker, 2011. G6PDH-activity in equine oocytes correlates with morphology, expression of candidate genes for viability, and preimplantative in vitro development. Theriogenology, 76 12151226.

Pandey, A., S. C. Gupta, and N. Gupta, 2010. Effect of FSH and LH hormones on oocyte maturation of buffalo and gene expression analysis of their receptors and $\mathrm{Cx} 43$ in maturing oocytes. Zygote, 18: 231-234.

Patel, O.V, A. Bettegowda, J. J. Ireland, P. M. Coussens, P. Lonergan, and G. W. Smith, 2007. Functional genomic studies of oocyte competence: evidence that reduced transcript abundance for follistatin is associated with poor developmental competence of bovine oocytes. Reproduction, 133:95-106.

Paula-Lopes, F. F., M. Boelhauve, F. A. Habermann, F. Sinowatz, and E. Wolf, 2007. Leptin promotes meiotic progression and developmental capacity of bovine oocytes via cumulus cell-independent and -dependent mechanisms. Biol. Reprod., 76:532-41.

Prasad, C. S., V. S. Gomathy, A. Palanisamy, G. D Raj, A. Thangavel, and S. Satheshkumary, 2010. OCT-4 gene expression pattern in different grades of buffalo (Bubalus bubalis) oocytes. Buffalo Bulletin 29 No. 2.

Rodman, T.C. and R. Bachvarova,1976. RNA synthesis in preovulatory mouse oocytes. J. Cell. Biol., 70: 251-257.

Smits, K., K. Goossens, A. Van Soom, J. Govaere, M. L. J. Hoogewijs, 2011. Peelman. In vivoderived horse blastocysts show transcriptional upregulation of developmentally important genes compared with in vitro-produced horse blastocysts. Reprod. Fertil. Dev., 23:364 -75

Stanton, J. L., and D. P. Green, 2002. A set of 1542 mouse blastocyst and preblastocystgenes with well- matched human homologues. Mol. Hum. Reprod., 8: 149-166.

Stanton, J. L., and D. P. Green, 2001. A set of 840 mouse oocyte genes with wellmatched human homologues. Mol. Hum. Reprod., 7: 521-543.

Torner, H., N. Ghanem, C. Ambros, M. Hölker, W. Tomek, C. Phatsara, H. Alm, M-A. Sirard, W. Kanitz, K. Schellander, and D. Tesfaye, 2008. Molecular and subcellular characterisation of oocytes screened for their developmental competence based on glucose-6-phosphate 
dehydrogenase activity. Reproduction, 135: 197212.

Wang, Q., and Q.Y.Sun,(2007). Evaluation of oocyte quality: morphological, cellular and molecular predictors. Reprod. Fertil. Dev., 19(1):1-12.

مقارنة التعبيير الجينى للجينات ذات العلاقة بجودة البويضة فى كلٍ من بويضات الجاموس و الجمال المنتجة معمليا

أشرف السيديد

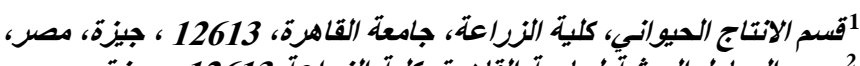
مجمع المعامل البجثية لجامعة الثقاهرة بكلية الزيراعة 12613 ، جيزة، مصرة

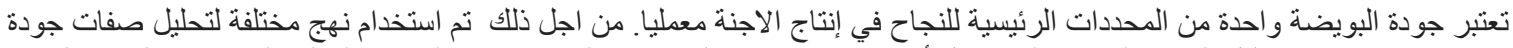

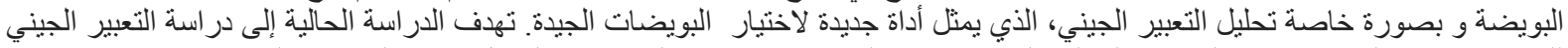

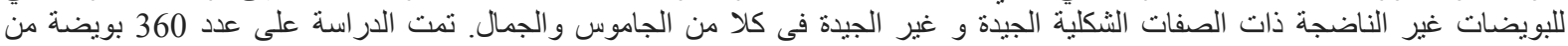

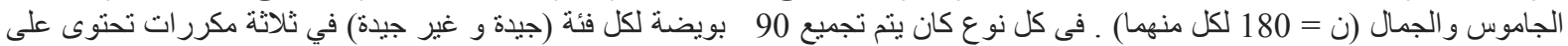

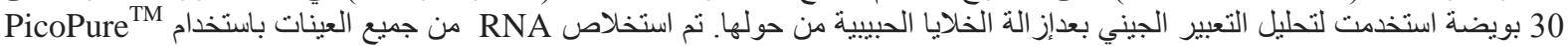

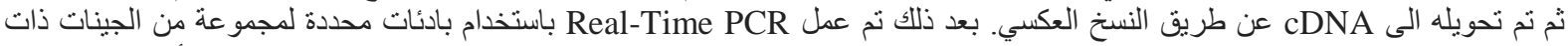

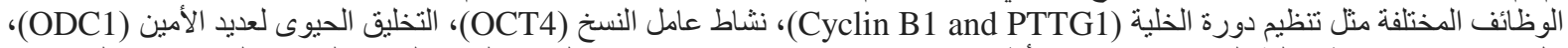

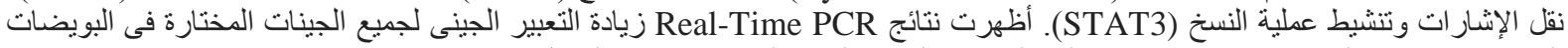
الجيدة مقارنة بغير الجيدة فيما عدا STAT3 الذى لم ينغير التعبير الجينى له فى بويضات الجمال. 